\title{
Thermal Monitoring of Photovoltaic module using Optical Fiber Sensors
}

\author{
Edson Antonio Santolin, Ivo de Lourenço Junior, Vinícius Dalla Corte \\ Federal University of Technology - Paraná (UTFPR), Pato Branco, Brazil, ZIP: 85503-390. E-mail: \\ edson.santolin@uffs.edu.br,lourenco@utfpr.edu.br,viniciuscorte@alunos.utfpr.edu.br \\ Jean Carlos Cardozo da Silva, Valmir de Oliveira \\ Federal University of Technology -Paraná,Curitiba, Brazil, ZIP: 80230-901.E-mail: jeanccs@utfpr.edu.br, \\ valmir@utfpr.edu.br
}

\begin{abstract}
This paper proposes the use of fiber Bragg gratings (FBG) in thermal monitoring of photovoltaic (PV) modules. Results acquired from FBG sensors were compared with two commonly used temperature sensing techniques in PV modules: PT100 sensors and infrared cameras. The experiments were performed using a PV module in actual operating conditions (varying ambient temperature and wind speed). Temperature changes in PV module were monitored with 27 FBG sensors installed on its front surface. During the experiments the ambient temperature, intensity of solar radiation and wind velocity were also monitored. The acquired results showed that FBG sensing technology has a potential for the proposed application.
\end{abstract}

Index Terms-Optical fiber sensor, photovoltaic module, thermal monitoring.

\section{INTRODUCTION}

After the oil shortage faced by industrial countries in the 70s, particularly in the period of 19731978 , other types of power generation were to be researched so that the energy problem could be solved by renewable sources to ensure the supply of the industrial needs in the world. This could be performed by focusing the research efforts on technologies of generation using solar and wind power, biomass, geothermal, hydro and hydrogen sources [1]. Among the currently used renewable energy sources, the use of photovoltaic models is strongly encouraged, especially by tax incentives and the development of technologies that made possible the on grid power production (eliminating the need to purchase batteries for energy storage, which reduces by approximately $40 \%$ the implementation costs of photovoltaic system). Over the past decade, the use of photovoltaic energy has grown at an average rate of 39\% per year, while the most used photovoltaic panels are based on mono or polycrystalline silicon and have $90 \%$ of the market share [2].

In contrast to the other renewable technologies for power generation, the development pace of the photovoltaic systems market share has been relatively slow. It indicates two major disadvantages based on the higher cost of the PV models and their lower energy efficiency (15\% to $21 \%$ for crystalline silicon panels). Among the eight major economic and technological goals of the photovoltaic industry to be achieved by 2020 , an increased conversion efficiency of commercial cells

Brazilian Microwave and Optoelectronics Society-SBMO received 08 June 2016; for review 09 June 2016; accepted 08 Sept 2016 
of monocrystalline silicon to $24 \%$, and polycrystalline to $19 \%$, is to be achieved, as well as the reduction of the rate degradation of modules $[2,3]$.

The increase in temperature can cause efficiency losses in the PV model. It is estimated that in a new panel, the generated output power is reduced at a rate of $0.5 \%$ per degree Celsius [4]. In PV models installed in ambient temperature conditions, the heating can be caused by weather conditions, energy production (PV module temperature) or even due to electrical or mechanical degradation of cells, leads and terminals.

The PV module performance is strongly affected by the solar irradiance and its temperature. Therefore, it is important to know the temperature of a solar PV model to predict its power output.

The measurement of temperature in photovoltaic models plays an essential role in testing technical standards for characterization and approval of panels (IEC 60904 and 61215), in the identification of generation profiles on installed panels in different climate regions [5] and in determining the electrical degradation rate of the cells $[6,7,8]$. However, the determination of the temperature of the cells in a PV module is not usually a practical task. It is not possible to directly measure the temperature on the cells using an encapsulated commercial module. This task becomes more complex in cases where the panel is working under actual operating conditions, where oscillations in the intensity of solar irradiance, speed and direction of the wind would generate thermal gradients along the surface of the panel $[4,9]$.

Currently the PV module operating temperature can be determined by several techniques. The direct measurement of the PV back surface temperature using a thermoresistive sensor (PT100, NTC, thermocouple) $[5,10,11]$, indirect measurement using infrared camera (IR), ultraviolet camera (UV) $[6,7]$ or using numerical modeling is a set of techniques that allow one to estimate the thermal behavior of a PV module [9].

The literature registers an ever growing number of publications in the study of fiber Bragg gratings (FBG) as sensor elements in several areas of the energy sector.

FBG sensors have been utilized to measure temperature in inverters in photovoltaic systems $[12,13]$. Such power circuits are used to convert constant currents (CC) to alternate currents (AC). The electrical process in the power circuit uses power trasistors switching that operate at high frequencies in environments with high levels of electromagnetic interference (EMI), justifying use FBG sensors.

In this scenario, this paper presents a study of the FBG application for temperature monitoring of a PV module in real operation condition. Also a thermal mapping of the PV module has been presented.

\section{FBG TECHNOLOGY}

The FBG is a periodic modulation of the core refractive index along an optical fiber, and it operates as a filter that reflects a sharp spectral peak at a particular wavelength, that is close to the Bragg 
wavelength $\left(\lambda_{B}\right)$, as shown in Fig.1. The Bragg wavelength is related to the spatial period of the modulation of the core refractive index $(\Lambda)$ and the effective index of the fundamental mode $\left(\eta_{\text {eff }}\right)$ in a single mode fiber [14].

Due to the thermo-optic coefficient and photo-elastic constant, when a fiber Bragg grating is subject to temperature changes $(\Delta \mathrm{T})$ or longitudinal mechanical stress $(\Delta \mathrm{l})$, such disturbances in the FBG result in a shift in the Bragg wavelength $\left(\lambda_{\mathrm{B}}\right)$ which can be detected by an interrogator [15]. For an FBG of Bragg wavelength at $1550 \mathrm{~nm}$ (nanometer), the sensitivity of a single mode ordinary fiber a deformation of $1 \mu \varepsilon$ (microstrain) results in a shift of $1.3 \mathrm{pm}$ (picometer) and a $1^{\circ} \mathrm{C}$ variation causes the Bragg wavelength to shift $10 \mathrm{pm}$. The shift in Bragg wavelength $\left(\Delta \lambda_{B}\right)$ with strain and temperature changes can be expressed using Equation (1) where the first term corresponds to strain and the second term corresponds to temperature changes.

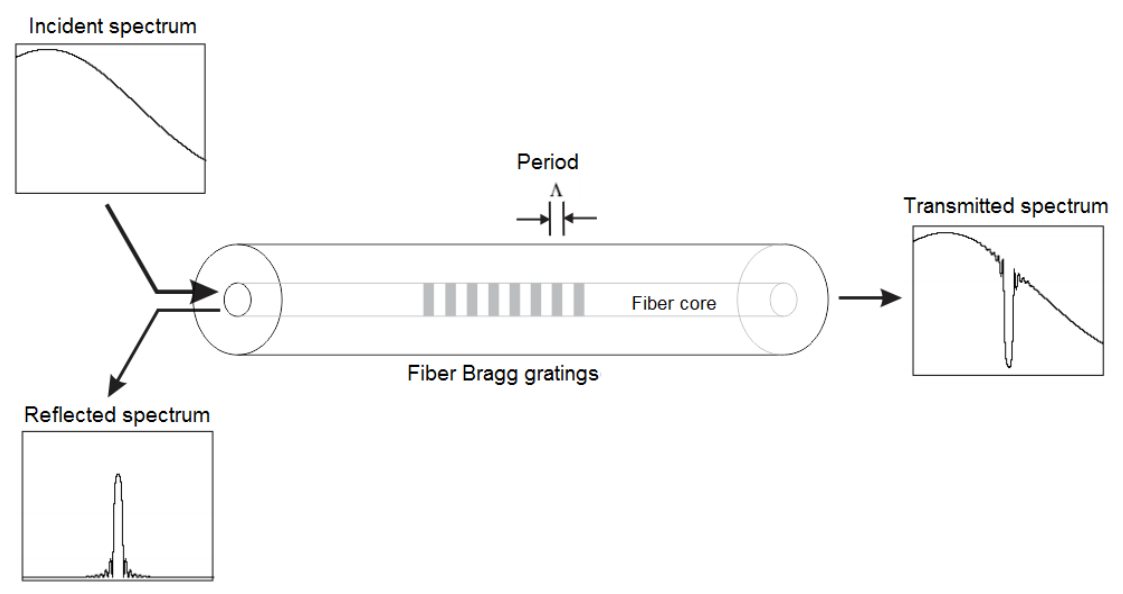

Fig.1. Functional principle of a Bragg grating fiber

$$
\Delta \lambda_{B}=2\left(\Lambda \frac{\partial_{\eta_{e f f}}}{\partial l}+\eta_{\text {eff }} \frac{\partial \Lambda}{\partial l}\right) \Delta l+2\left(\Lambda \frac{\partial_{\eta_{e f f}}}{\partial T}+\eta_{\text {eff }} \frac{\partial \Lambda}{\partial T}\right) \Delta T
$$

where $\frac{\partial_{\eta_{e f f}}}{\partial l}$ is the change in fiber effective index due to photoelastic effect, $\frac{\partial \Lambda}{\partial l}$ is the physical elongation of the sensor (corresponding fractional change in the grating spacing), $\frac{\partial_{\eta_{\text {eff }}}}{\partial T}$ is the change in fiber effective index due to thermo-optic effect and $\frac{\partial \Lambda}{\partial T}$ is the inherent thermal expansion of the fiber material.

Due to the small size of the fiber, to the possibility of sensor multiplexing, response to linear behavior, high accuracy and sensitivity and immunity to electromagnetic interference (EMI), fiber sensors have attracted an considerable interest from the researchers, thus FBGs are widely used as sensor elements,. Also, FBGs are also designed for applications in the measurement at high temperatures $\left(1100^{\circ} \mathrm{C}\right)$, such as boilers, pipes and even nuclear reactors [16], and measurement at low temperatures $\left(-253^{\circ} \mathrm{C}\right)$, such as in the monitoring of cryogenic systems [17].

Brazilian Microwave and Optoelectronics Society-SBMO received 08 June 2016; for review 09 June 2016; accepted 08 Sept 2016 
FBG sensors are immune to electromagnetic interference (EMI) and have been used in areas of high EMI, such as monitoring of the thermal variation of stators, motors and generators [18], inside of bearings and thyristor bridges [19]; dynamic monitoring of composite structures in service, allowing thermal expansion monitoring; movement of the foundation piles to monitor their integrity[20] and to the study of mechanical deformation from latex paint drying process[21].

\section{CONVENTIONAL TECHNIQUES FOR THERMAL MONITORING IN PHOTOVOLTAIC MODULE}

Nowadays, a wide variety of techniques has been demonstrated for the measurement of the PV module temperature. The most commonly used technique is based on the use of thermoresistive sensor (normally a PT100 sensor [5, 10, 22] or thermocouple [23]), installed exactly in the middle of its rear surface. This option is frequently used due to the fact that the sensors which are fixed on the front surface can produce shading in cells, causing the performance of the power output of a PV module to deteriorate. The temperature measured at that point is considered as the average temperature of the PV module [24].

This method has a relatively low cost and easy installation, and is widely used in indoor measurements or in situations where the PV module temperature is controlled with a cooling system to keep the module to within certain temperatures. In actual operating conditions some experiments also use this method, however in real world applications, which is subject to the incidence of winds, the thermal gradient generated by air movement can reveal significant uncertainty in the determination of the mean panel temperature, since the temperature is measured in a single point [25]. This is also used in experimental setup for technical standards, performance analysis of PV module and validation of the thermal model for PV modules.

Another temperature measuring method in PV modules uses thermographic cameras, which detects the level of infrared radiation (IR) emitted by the PV module, and also captures a thermal image that indicates the module temperature. In this technique, the measurement is indirectly performed, knowing that the sensing system does not have a physical contact with the module. Due to practicality requisites, the front surface of the module is normally used.

This method is used to capture the thermal gradient in PV module $[6,7,8]$. The images obtained by IR Image generate a matrix of hundreds of points (depending on the thermal resolution of each thermal image). An image can be produced reaching high resolution and allowing one to detect thermal gradients, which are caused by the incidence of winds, changes in the incoming solar radiation and changes in the weather conditions. Additional problems as in hotspots and solar cell cracks and micro cracks are related to electrical and mechanical degradation of the PV module. The IR Image is commonly used in inspections of the degradations in PV modules that are installed in solar power plants.

Brazilian Microwave and Optoelectronics Society-SBMO received 08 June 2016; for review 09 June 2016; accepted 08 Sept 2016 


\section{PACKAGING AND CHARACTERIZATION OF OPTICAL FIBER SENSORS}

The optical fiber sensors used in this work were produced in the photonics laboratory at the UTFPR - Curitiba, using an interferometric fabrication technique to imprint the Bragg gratings in optical fibers with a phase mask [26]. FBG sensors were easily multiplexed in a serial fashion along an optical fiber using four optical fiber strands. A set of seven fiber Bragg gratings (each one located at a distance of 14,0 cm from each other) was produced, and one of the sets had six FBGs (located at a distance of $16,7 \mathrm{~cm}$ from each other). A total of 27 sensors were used to monitor temperature changes in the PV module depicted in Fig.2.

The sensors are identified by $C_{x \_} S_{y}$, where $C_{x}$ corresponds to the fiber cable number $x=1,2,3$ or 4 and $\mathrm{S}_{\mathrm{y}}$ corresponds to the sensor in this fiber, $\mathrm{y}=1,2,3$ or 4 .

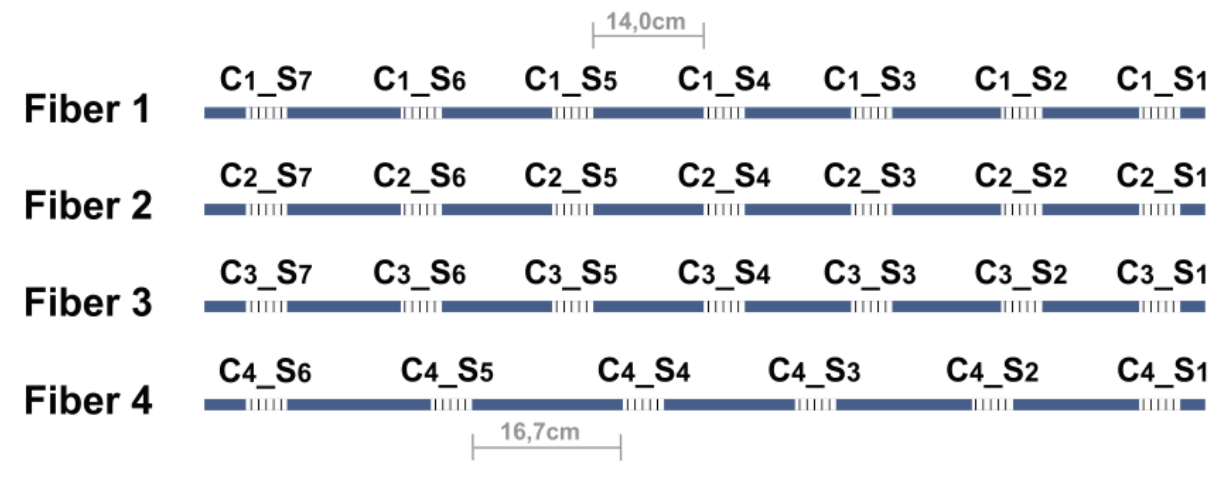

Fig.2. Distribution of fiber Bragg gratings in fibers

Bare FBGs are fragile and must be handled carefully. As a consequence, a suitable package should be designed before being used to measure the temperature of PV module.

For this purpose, the 27 FBG sensors were packaged using the technique presented in [19] and [28]. This technique uses a steel tube (commercial syringe needle), where the Bragg grating is fixed in its interior Fig.3(a).

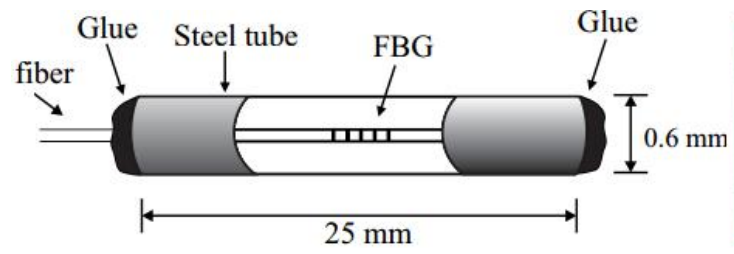

(a)

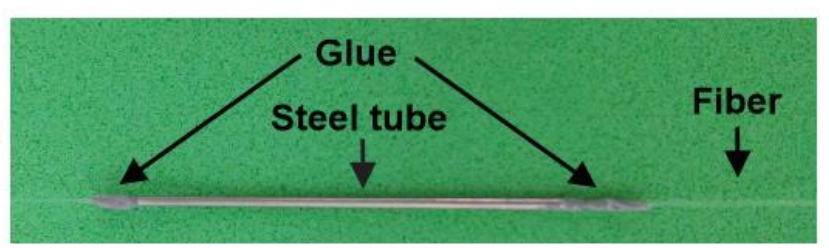

(b)

Fig.3. Package technique [28] (a) and the optical fiber after encapsulation (b)

This method also protects the core from mechanical stresses arising in the optical fiber attachment to the front surface of the PV module or from the thermal expansion that eliminates problems related 
to the cross-sensitivity effect. Due to the small size of the steel tube, shading will not occur on the panel.

The stainless steel needle used for the FBG packaging has a length of $25.0 \mathrm{~mm}$, outer diameter of $0.6 \mathrm{~mm}$ and inner diameter of $0.4 \mathrm{~mm}$. A two-component epoxy type waterproof glue was used for the bonding the optical fiber at the ends of the needle. The fully packaged fiber can be seen in Fig.3(b).

After packaging FBGs sensors, fiber cables were subjected to a thermal characterization process. For this purpose, the optical fibers were placed inside a hollow copper tube, which has its external wall totally immersed in a continuous flow of DC510 silicone oil.

The oil temperature was controlled by a circulating bath from Polyscience, 9002A11B model with precision of $0.25^{\circ} \mathrm{C}$, temperature stability of $\pm 0.01^{\circ} \mathrm{C}$ and operating temperature range between $20.0^{\circ} \mathrm{C}$ to $200.0^{\circ} \mathrm{C}$. For the monitoring of the Bragg wavelength shift of FBGs sensors, the characterization of temperature was carried out by an optical interrogator (model DI410, by MicronOptics, resolution of $1 \mathrm{pm}$ and tunable laser source with spectrum of 1510 to $1590 \mathrm{~nm}$ ). The recording of characterization data was performed by an interrogator software. The characterization system is shown in Fig.4.

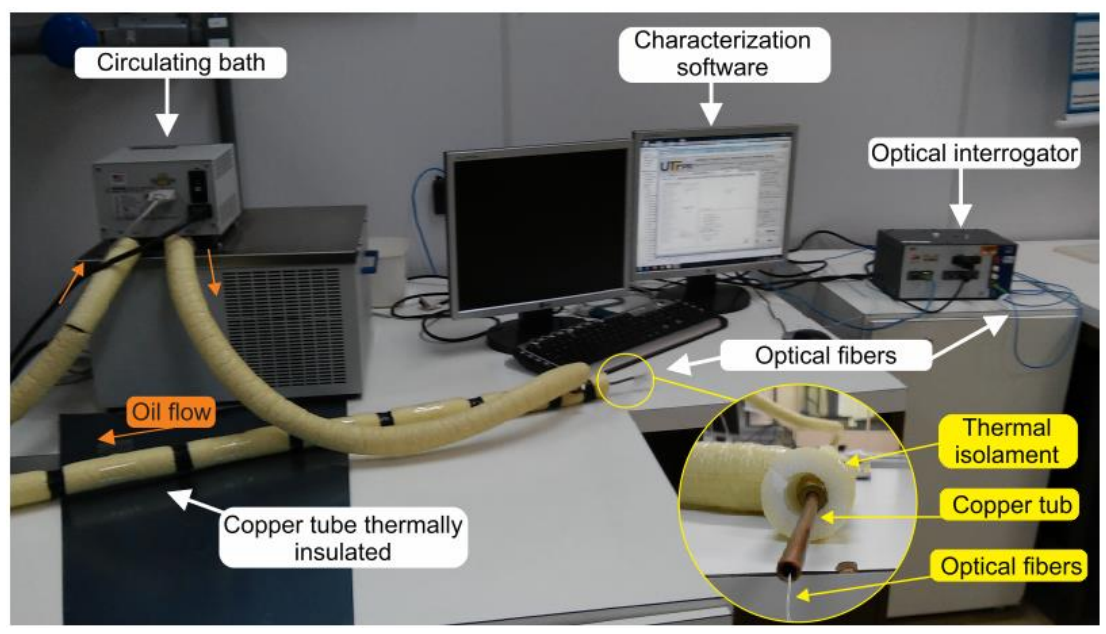

Fig.4. Characterization system of optical fibers

The characterization was carried out in five tests, and at each test the temperature was increased from $10.0^{\circ} \mathrm{C}$ to $70.0^{\circ} \mathrm{C}$ in incremental steps of $10.0^{\circ} \mathrm{C}$, using a circulating bath, and the resonance Bragg wavelength shift was acquired. At the end of the process, the linearity coefficients of each sensor and the combined uncertainties associated with the process of characterization and the equipment used [29].

The PT100 sensor was also characterized using the same system (circulating bath). The wide temperature range for the calibration was between $10.0^{\circ} \mathrm{C}$ to $70.0^{\circ} \mathrm{C}$, in incremental steps of $10.0^{\circ} \mathrm{C}$. With the data collected, the PT100 characteristics were also found. 


\section{EXPERIMENTAL SETUP}

The experimental setup was implemented in the laboratory of POLITEC at the UTFPR campus Pato

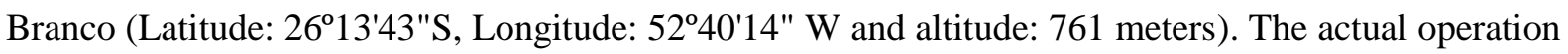
condition, measurements were taken under changing atmospheric condition.

The technical characteristics of the PV module provided by the manufacturer are polycrystalline PV module of $87.0 \mathrm{~W}$, installed on a metal platform with $35^{\circ}$ inclination and its front face was directed to the north. The optical fibers were fixed on the glass cover of the PV module, being distributed each other in parallel, with a distance of $15.0 \mathrm{~cm}$ between consecutive sensors. The sensors were fixed by using a silicon thermal grease. The distribution of the FBGs sensors on the glass cover of the PV module is shown in Fig.5.

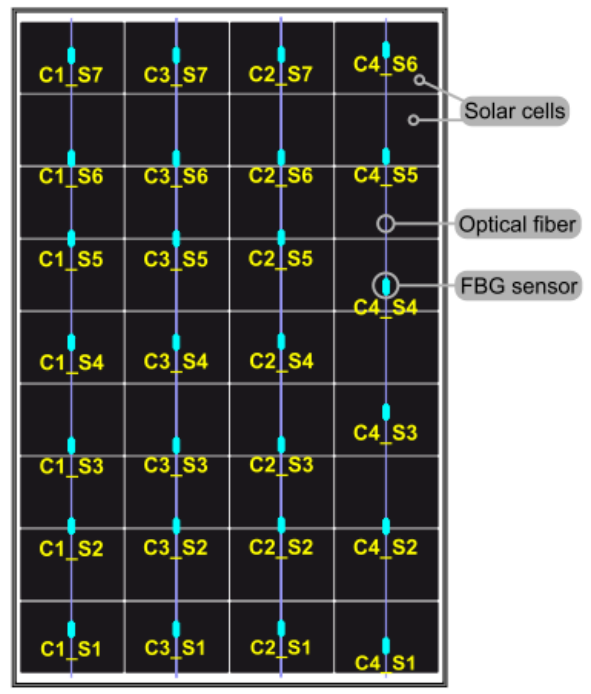

Fig.5. FBGs sensors on the glass cover of the PV module

After the packaging of the 27 FBGs sensors, the fibers were connected to the optical interrogator type DI410, that was linked to a personal computer (PC). Temperature measurements data from FBGs sensors were recorded in steps of 1 second and the arithmetic mean of 27 points was calculated.

To reproduce the single point measurement method using a thermoresistive sensor, a PT100 sensor (manufactured by ECIL enterprise) was installed exactly in the center of the back surface of the PV module. To minimize the influence of ambient temperature on the measurement, a thermal insulator of polystyrene fixed on the back of the sensor was also used.

The changes in the incoming solar radiation, wind speed and ambient temperature were monitored using a global radiation pyrometer (SPLite model, manufactured by Kipp\&Zonen), one shell anemometer (M-3 model, manufactured by Meteor) and a precision temperature sensor (LM35 model, manufactured by National Semiconductor).In the experiments, output current or voltage from the PV module, the measurements of voltage and current were acquired through a resistive bridge and a Hall effect current sensor (ACS755LCB-050 manufactured by Allegro Microsystem).

Brazilian Microwave and Optoelectronics Society-SBMO received 08 June 2016; for review 09 June 2016; accepted 08 Sept 2016 
Except for the FBGs sensors, all the other sensors were connected to a signal conditioning interface, which amplifies and filters the signals, conditioning the electrical levels to a compatible level for the connection with the USB data acquisition interface (model NI USB-6259 BNC, manufactured by National Instruments).The acquiring interface transmits the sensor data to a computer (PC) with an acquisition period of 1 second.

\section{RESULTS}

Data analysis was performed comparing the measurements obtained by the optical fiber sensors to the PT100 sensor data and to thermal imaging obtained with the infrared camera. This analysis also sought to highlight the behavior of sensors while detecting temperature variations with the PV module subject to two specific conditions.

The first condition corresponds to an open circuit at the output of the PV, to explore the sensors to detect the temperature variations induced only by environmental changes. If the PV module was left in open circuit voltage, most of the incoming solar radiation would be converted to heat [30].

The second operating condition corresponds to the PV module with output electrical current to exploit the ability of the sensors to detect overheating caused by cell defects.

\section{A. FBGs sensors versus PT100 (open circuit voltage - current is not flowing)}

During the test in open circuit voltage, as seen in Fig.6 (a), it should be observed that both the PT100 sensor and FBGs sensors results exhibit similar trend curves for average temperature. In Fig.6(b), the environmental conditions during the analyzed time period are presented, where the variations in wind speed are presented every second (as collected during the experiment) and every minute (as calculated by arithmetic mean).

Brazilian Microwave and Optoelectronics Society-SBMO received 08 June 2016; for review 09 June 2016; accepted 08 Sept 2016 


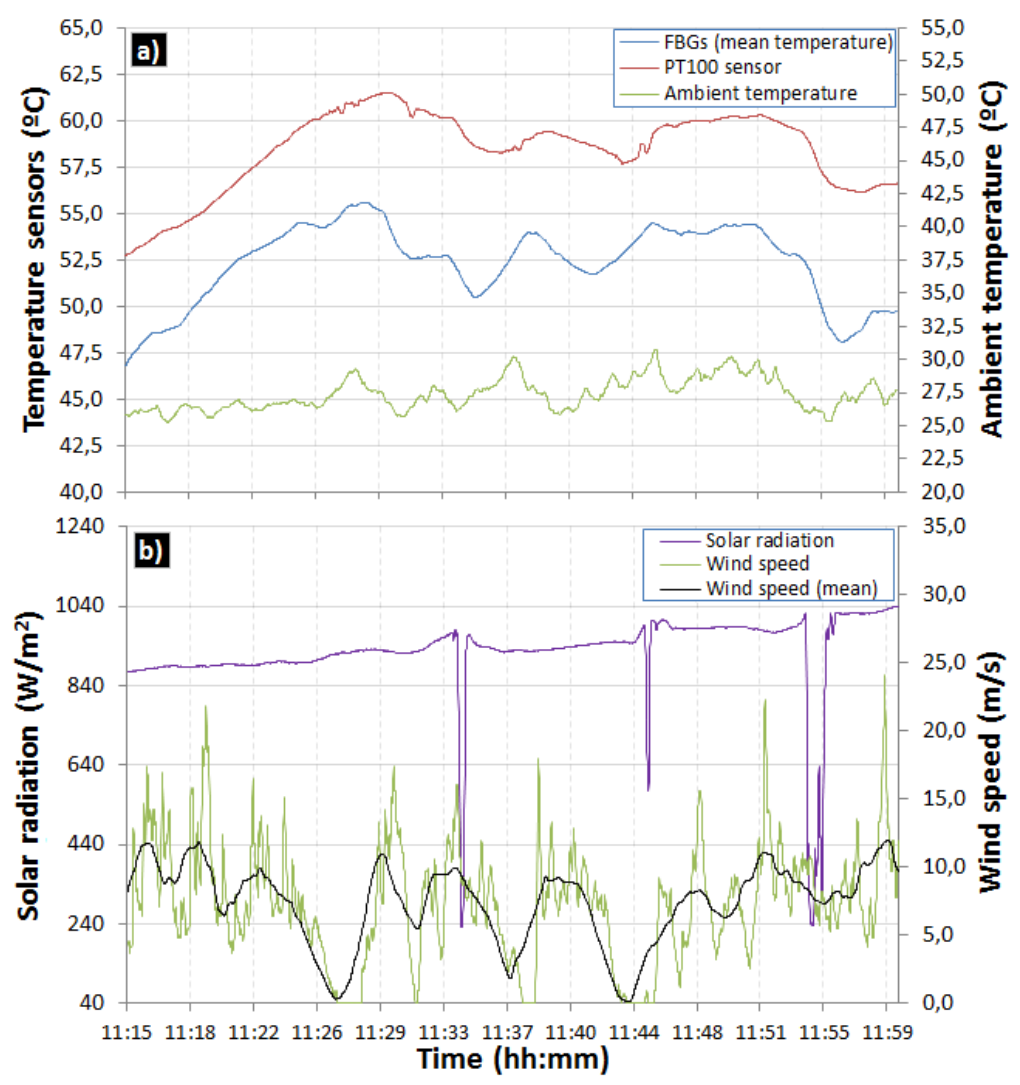

Fig.6. Temperature measured with PT00 sensor versus the mean temperature obtained with the fibers (a) under changes in environmental conditions $(\mathrm{b})(\mathrm{R}=0.47 \Omega)$

During the experiment, the occurrence of cloud cover at three different moments caused the PV module temperature to be affected. At $11 \mathrm{~h} 45 \mathrm{~min}$, a second cloud cover of about 9 seconds did not affect the measured temperature, keeping the same heating curve before the occurred. Probably due to PV module large thermal mass.

During this period, the PV module temperature increased, as the low wind speed was not significantly contributing to the model cooling. The heating effect caused by solar radiation took a significant role. However, the obstruction of the solar radiation for some periods of time, such as at $11 \mathrm{~h} 34 \mathrm{~min}$ (21 seconds obstruction) caused a reduction of $2.2^{\circ} \mathrm{C}$ in the $\mathrm{FBGs}$ and of $1.6^{\circ} \mathrm{C}$ in the PT100. At $11 \mathrm{~h} 54 \mathrm{~min}$ (1min06s obstruction), a reduction of $2.9^{\circ} \mathrm{C}$ in the mean temperature of FBGs and $2.4^{\circ} \mathrm{C}$ in the mean temperature of PT100 was recorded.

Throughout the experiment, the temperature measured by the PT100 sensor remained always higher, reaching sometimes up to $6.5^{\circ} \mathrm{C}$ above the mean temperature of the FBGs (periods from 11h36min, 11h59min and 11h35min).

The difference between measured temperatures using PT100 sensor and average temperatures in sensing fibers is caused by two main reasons. In the first one, the PT100 sensor is located in the central region of the panel that is also a spot having the largest increase in temperature. In the second case, average temperatures obtained by the FBGs have average values calculated from 27 signals from sensors distributed over the panel surface. Therefore, regions with smaller temperatures than the Brazilian Microwave and Optoelectronics Society-SBMO received 08 June 2016; for review 09 June 2016; accepted 08 Sept 2016 
values measured by the PT100 may be detected. The peripheral area in the panel usually has lower temperatures than the added regions.

It is possible to notice that the larger differences observed in periods of time with higher speed of wind are related to the larger cooling of the most outer parts of the module surface, reducing the mean temperature of the FBGs.

The smallest difference observed was $4.4^{\circ} \mathrm{C}$ and occurred at $11 \mathrm{~h} 26 \mathrm{~min}$ and $11 \mathrm{~h} 44 \mathrm{~min}$. During these periods of time, the intensity of solar radiation is nearly constant and the wind speed up to $5 \mathrm{~m} / \mathrm{s}$ allowed a greater thermal equilibrium of the PV module. Then, the mean temperature measurements of the FBGs tended to the temperature measured by PT100 installed in the center of the PV module back surface.

The cooling effect in peripheral areas of the PV module is evidenced when analyzing individually each FBG sensor, which presents high values of temperature. For the same period of time, significant temperature changes in PV module surface are observed, showed in Fig.7.The maximum difference registered was $9.8^{\circ} \mathrm{C}$.

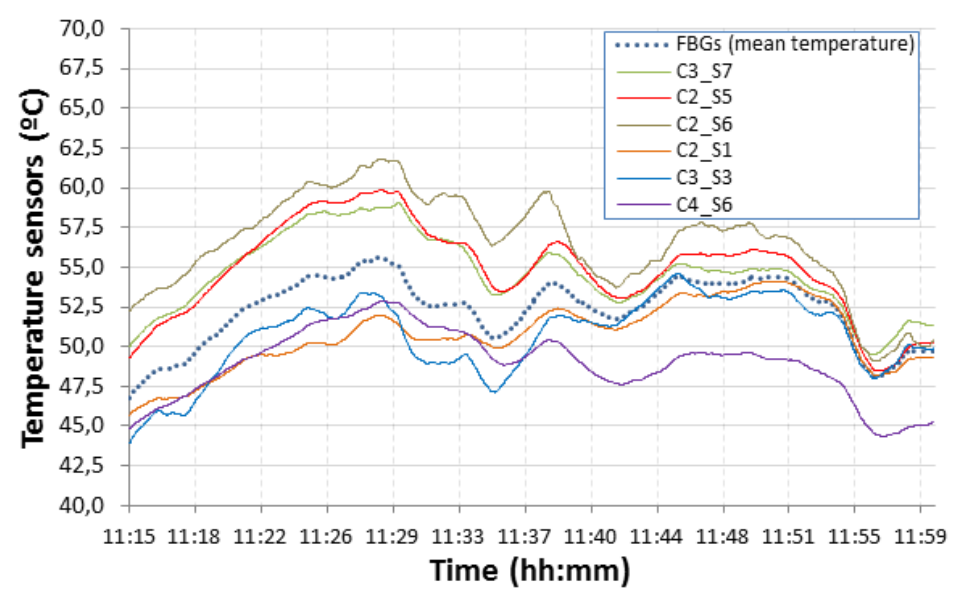

Fig.7. Comparison of the mean temperature of FBG with the six most extreme temperature measurements

B. FBGs sensors versus PT100 (current is flowing within the module)

The behavior of the measurements of the FBGs sensors and PT100 was also compared.

In order to illustrate the behavior of the measurements obtained with the FBGs and the PT100, the PV module was connected to different resistive loads to allow the current to flow from 0A to short circuit current $\left(\mathrm{I}_{\mathrm{SC}}=5.34 \mathrm{~A}\right)$. Due to the appropriate electrical connections of the module, significant temperature variations in the cells were only observed from a value close to the $\mathrm{I}_{\mathrm{SC}}$ current, with a load having a relatively low resistance $(\mathrm{R}=0.47 \Omega)$. It is important to note that when considering a constant resistive load, the current flowing in the PV module is directly proportional to incident solar radiation in this module. Therefore, it was possible to generate an output current with a value close to $\mathrm{I}_{\mathrm{SC}}$ produced by a solar radiation intensity higher than $600 \mathrm{~W} / \mathrm{m}^{2}$. 
In Fig.8 (a) the curves of the mean temperature for both sensors FBGs and PT100 sensor are depicted. PT100 values always have a larger value than the temperature registered by the FBGs, with a maximum registered difference of $5.2^{\circ} \mathrm{C}(13 \mathrm{~h} 08 \mathrm{~min})$, and minimum of $2.4^{\circ} \mathrm{C}(13 \mathrm{~h} 07 \mathrm{~min})$.
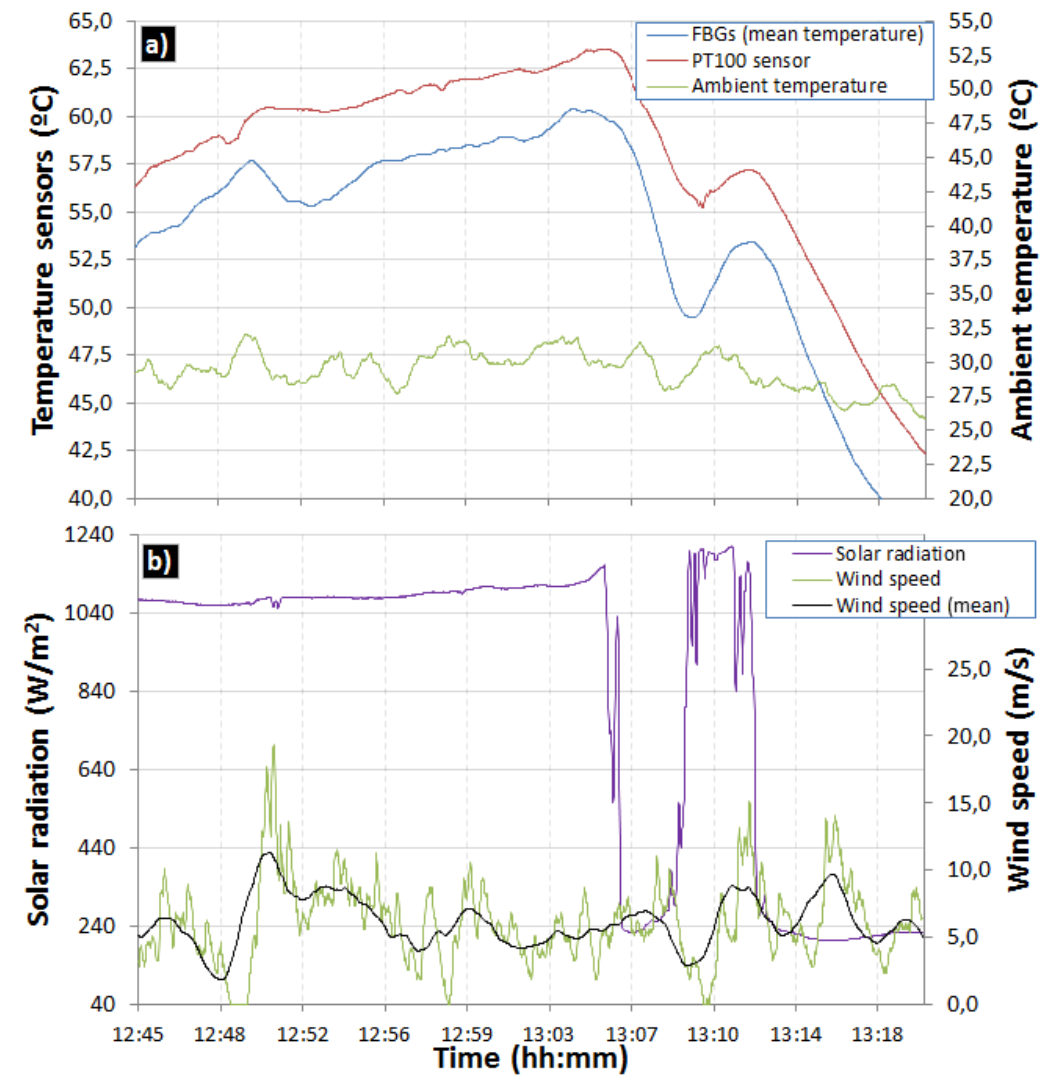

Fig.8. Temperature measured with PT00 sensor versus mean temperature obtained with the FBG (a) under changes in environmental conditions (b) $(\mathrm{R}=0,47 \Omega)$

However, when the analysis of the mean temperature of each FBGs sensor was performed, it was observed that some measured points presented significant differences in the registered temperatures, as shown in Fig.9.

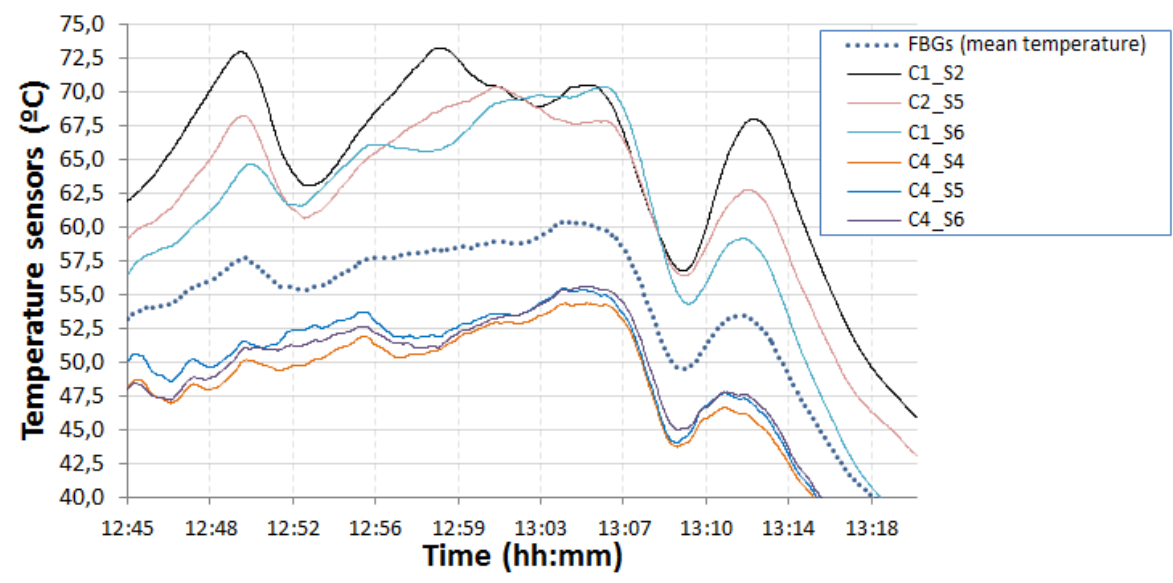

Fig.9. Comparison of the mean temperature of FBGs with the six most extreme temperature measurements 
Significant discrepancies occur in the observed case at $12 \mathrm{~h} 49 \mathrm{~min}$, when the $\mathrm{C}_{2} \mathrm{~S}_{1}$ sensor was at $72.6^{\circ} \mathrm{C}$, and the $\mathrm{C}_{4} \_\mathrm{S}_{4}$ sensor, at $50.0^{\circ} \mathrm{C}$, possibly indicating that in the region where the $\mathrm{C}_{2} \mathrm{~S}_{1}$ was installed, a cell overheating due to electrical degradation or resistive mismatching with other cells occurred while connected in series. At this point, it has also been observed that this heating occurred due to a period of time with low incidence of winds.

With the use of an infrared camera, it was observed that the cells monitored by sensors $C_{1} S_{2}$, $\mathrm{C}_{2} \mathrm{~S}_{5}$ and $\mathrm{C}_{4-} \mathrm{S}_{5}$ have higher registered temperatures than the other sensors.

Another observed feature in these cells is that the thermal variations are higher. It can be seen between 13h08min and $13 \mathrm{~h} 12 \mathrm{~min}$, where after a period of time with low solar radiation incidence $\left(240 \mathrm{~W} / \mathrm{m}^{2}\right)$, due to sun obstruction by a cloud cover, the incidence level increased $\left(1231 \mathrm{~W} / \mathrm{m}^{2}\right)$. During this period of time, the cell monitored by $\mathrm{C}_{1} \mathrm{~S}_{2}$ sensor increases its temperature from $56.9^{\circ} \mathrm{C}$ to $67.6^{\circ} \mathrm{C}$. In the same period of time, a cell without defects that was being monitored by the $\mathrm{C}_{4} \mathrm{~S}_{5}$ sensor varied its temperature from $44.6^{\circ} \mathrm{C}$ to $47.5^{\circ} \mathrm{C}$.

In general, for both assays the average of the FBGs and the PT100 temperature showed the behavior of their similar curves, a difference between them being only observed in the range of $3.3^{\circ} \mathrm{C}$ to $7.2^{\circ} \mathrm{C}$ (no current) and $2.1^{\circ} \mathrm{C}$ to $5.2^{\circ} \mathrm{C}$ (with current close to $\mathrm{I}_{\mathrm{SC}}$ ).

FBG sensors present a suficiente sensitivity for the detection of electrical problems in photovoltaic cells that are evidenced by positive thermal changes in the registered values. Since the current commercial photovoltaic panels are sealed, it is not feasible to change the deteriorated cells that are overheating without damaging the others. Therefore, registered temperature measurements can be used to identify possible causes of such problems like poor quality cells, failures in the panel fabrication process, resistive mismatch between cells, among other problems.

\section{FBGs sensors versus thermal imaging (current is not flowing)}

In the experimental setup, an infrared camera was used (model TI-25, manufactured by Fluke, measurement range $-20^{\circ} \mathrm{C}$ to $350^{\circ} \mathrm{C}$, precision of $\pm 2^{\circ} \mathrm{C}$ ).

The thermal gradient of the PV module was measured by the 27 FBGs sensors. With the results obtained from the distributed FBG sensors, a map with the temperature location on the PV module surface was generated in color scale, as shown in Fig.10(a).

The thermal gradient obtained by the thermal image was captured by setting the emissivity $(\varepsilon)$ equal to 0.85 (glass emissivity). For a better visualization, where the FBGs sensors were installed, the FBG location is identified being represented by P1 to P27.

The images were registered by an infrared camera with an automatic scale bar for enhanced image resolution, as illustrated in Fig.10(b).

Brazilian Microwave and Optoelectronics Society-SBMO received 08 June 2016; for review 09 June 2016; accepted 08 Sept 2016 
The differences of maximum and minimum temperatures values between the points measured by the FBGs and the values obtained by the infrared camera for the same points were around $2.90^{\circ} \mathrm{C}(\mathrm{P} 3)$ and $-1.52^{\circ} \mathrm{C}(\mathrm{P} 26)$, with solar radiation intensity of $980 \mathrm{~W} / \mathrm{m}^{2}$ and wind speed of $0.5 \mathrm{~m} / \mathrm{s}$.

As the wind incidence was assumed to be zero, it was observed that thermal variations caused by the heat from the incident solar radiation exposure and cooling due to the free convection can be detected by the FBGs sensors, acquired from the bottom of a heated inclined PV module.

Natural convection of air is significant and temperature of the inferior part of the PV module being colder than the superior part.
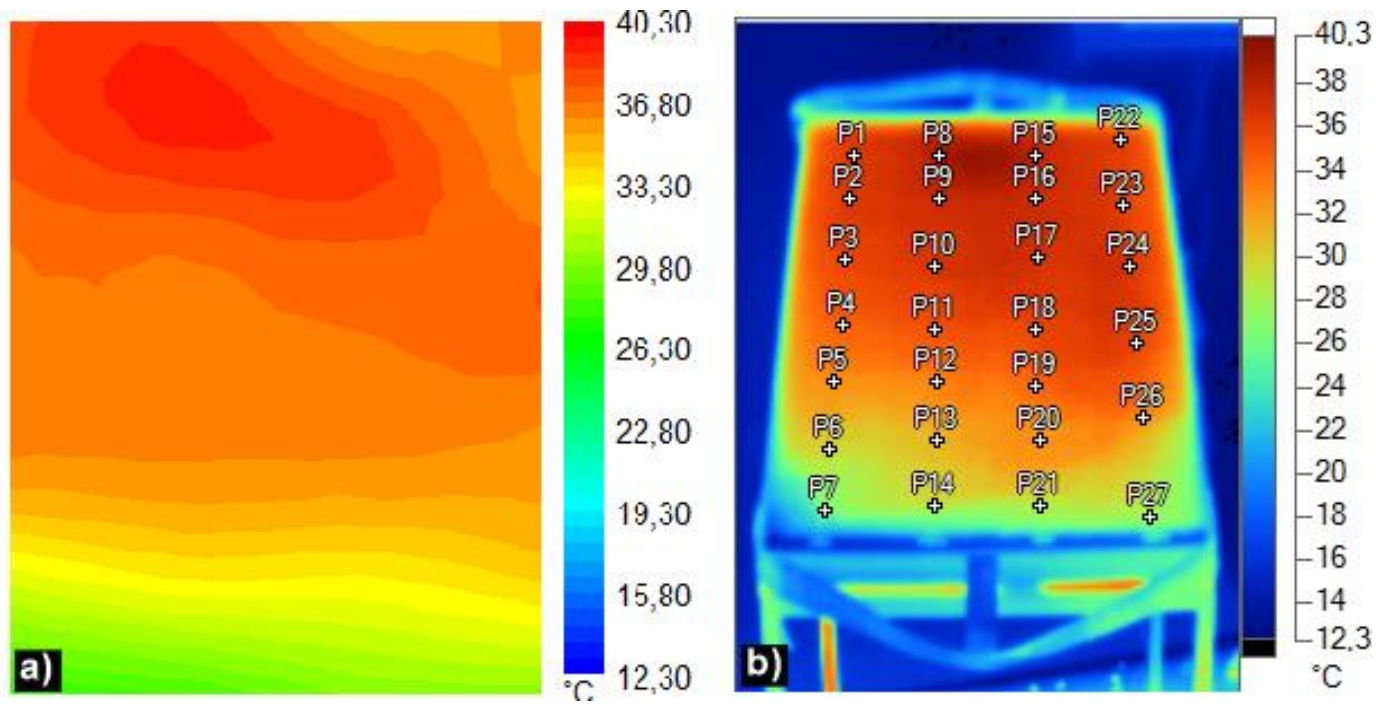

Fig.10. Thermal gradient obtained with FBGs sensor(a) with infrared camera (b)

\section{FBGs sensors versus infrared camera (current is flowing within the module)}

Now current is flowing within the module and in Fig.11(b) five regions with the hottest cell (P2, P4, P6, between P8 and P15, P17 and P24) were detected by the infrared camera. The FBGs have found all those hot regions, except the region between P8 and P15 since it was a blind spot to the FBG sensors, as can be seen in Fig.11(a).

In this specific region, the heat had no direct contribution caused by cells with problems, and is due to the module box that is installed on back surface of the PV module, exactly in this region. The air temperature in the closed box increased and the convective heat flow allowed the thermal energy to be transferred to that region in the PV module. The greatest temperature differences between the measurements of FBGs and the thermal images at the same points were $-0.41^{\circ} \mathrm{C}(\mathrm{P} 1)$ and $3.66^{\circ} \mathrm{C}$ (P16).

It is possible to observe the cells that have the higher temperatures with the thermal image obtained by the infrared camera. The cells shape can be visualized with the same image.

In the generation of the thermal gradient created by software, the heating points are detected, even though the limitation of the area of each cell is not shown. To make this gradient clearer, a possible 
solution would be to implement a mathematical model to limit the area of each cell, allowing a more realistic approach to thermal panel distribution.

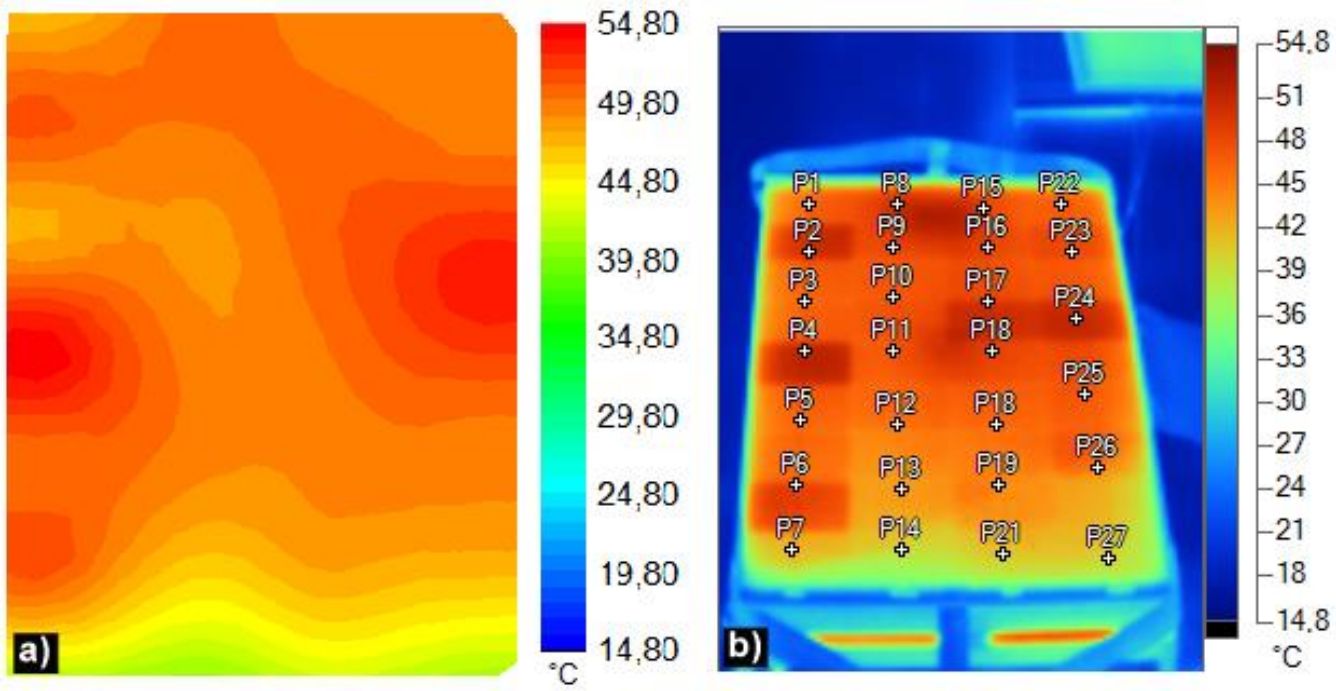

Fig.11. Thermal gradient obtained with FBGs measurement (a) with infrared camera (b) $(\mathrm{R}=0,47 \Omega)$

\section{CONCLUSION}

It has been demonstrated that FBGs sensors can be used for temperature measurements and are suited to be attached to the cover glass in the PV module. The FBG sensors were sensitive to temperature changes caused by the distributed heat on the cells and the thermal gradients caused by natural convection and wind incidence.

For quasi-distributed temperature monitoring on the frontal surface of the PV module, the FBG sensors were able to register a mean temperature of the PV module in ambient temperature condition. They have yielded good agreement when compared with traditional PT100 sensor and a superior performance to measure quasi-distributed sensors in the PV module.

The improvement of the quality in temperature measurements obtained with the FBGs can significantly contribute to the quality of tests based on technical standards for photovoltaic panels in open environments. This become more evident in the case of determination of energy conversion performance (IEC 60904) and electrical and mechanical degradation tests in panels (IEC 61215). In such tests, operating temperature is a critical parameter for homologation and qualification of evaluated panels.

Thermal mapping produced by the FBG sensors also allow an improved resolution in the registration of temperature variations at each panel region. Those temperature changes gradually deteriorate cells, tracks and conections in the panel. The use of such sensors for the thermal mapping is an important tool for the study of improvements in the constructive process of panels.

The measurements made with the infrared camera demonstrated that thermal image has a high resolution, but the monitoring with thermal images is an obstacle that will have to be overcome.

Brazilian Microwave and Optoelectronics Society-SBMO received 08 June 2016; for review 09 June 2016; accepted 08 Sept 2016 
The thermal mapping carried out with FBG scan be performed, however sensors must be attached to the glass cover.

The use of FBGs sensors was proven to be an attractive option to monitor thermal variations of the PV module. The monitoring process performed along several hours or days does not require the constant presence of the operator to capture thermal images during data collection.

Due to the fragility of FBGs sensors for use in usual weather conditions, the sensors must be packaged. The use of small metal tubes for packaging did not cause shadings in the cells, allowing stable and consistent measurements of the surface temperature of the module, proving to be an attractive option for this type of application.

\section{ACKNOWLEDGEMENTS}

The authors acknowledge the funding agencies CNPq, CAPES, FINEP and Fundação Araucária. Also acknowledge the Grupo de Pesquisa Dispositivos Fotônicos e Aplicações from UTFPR associated to the INCT Fotonicom for recording of the used FBGs.

\section{REFERENCES}

[1] L. Fraas, L. Partain, "Solar cells and their applications", 2 ed. 644p. John Wiley \& Sons Inc. New Jersey, 2010.

[2] International Energy Agency (IEA), “Technology roadmap: Solar photovoltaic energy”, OECD/IEA, IEA publications, Paris 2014.

[3] N. Darghouth, G. Barbose, R. Wiser, "Electricity Bill savings from residential photovoltaic systems: Sensitivities to changes in future electricity market conditions", in Market Conditions. Ernest Orlando Lawrence Berkeley National Laboratory, 82p. Berkeley, 2013.

[4] A. Luque, S. Hegedus, "Handbook of photovoltaic science and engineering", John Wiley \& Sons Inc, 2003.

[5] M. Fuentes, G. Nofuentes, J. Aguilera, D. L. Talavera, M. Castro, "Application and validation of algebraic methods to predict the behaviour of crystalline silicon PV modules in mediterranean climates”, in Solar Energy, vol. 81, issue 11, November 2007, p. 13961408, ISSN 0038-092X.

[6] G. Acciani, G. B. Simione, S. Vergura, "Thermographic analysis of photovoltaic panel”, in European Association for the Development of Renewable Energies, Environment and Power Quality (EA4EPQ), International Conference on Renewable Energies and Power Quality (ICREPQ'10), 3p. March 2010.

[7] W. Herrmann, "How temperature cycling degrades photovoltaic-module performance" in International Society Advancing an Interdisciplinary Approach to the Science and Application of Light (SPIE), doi: 10.1117/2.1201007.003177, 2010.

[8] J. Wohlgemuth, W. Herrmann, "Hot spot testes for crystalline silicon rtd in Photovoltaic Specialists Conference, 2005, Conference Record of the Thirty-first IEEE, p. 1062-1063, doi: 10.1109/PVSC.2005.1488317, 2005.

[9] A. Q. Jakhrani, A. K. Othman, A. R. Rigit, S. R. Samo, "Comparison of solar photovoltaic module temperature models", in World Applied Sciences Journal 14 (Special Issue of Foods and Environment), p. 11, 2011, ISSN: 1818-4952.

[10] M. A. Bohórquez, L. M. Gomes, J. M. A. Marquez, "A new and inexpensive temperature-measuring system: Application to photovoltaic solar facilities", in Solar Energy, vol. 83, p. 883-890, 2009, ISSN: 0038-092X.

[11] A. H. Fanney, B. P. Dougherty, "Building integrated photovoltaic test facility", in Journal of Energy Engineering, Especial issue: Solar Thermochemical Processing, vol. 123, n. 2, p. 194-199, 2001.

[12] N. Tamchek, A. P. Michael, S. R. Sandoghchi, M. R. Hassan, K. D. Dambul, J. Selvaraj, N. A. Rahim, F. R. Mahamd Adikan, "Design, characterization and implementation of a fiber Bragg grating temperature sensor for application in solar power electronic inverters”, in Applied Solar Energy, vol. 47, n. 3, p. 184-188, 2011, doi: 10.3103/S0003701X11030182.

Brazilian Microwave and Optoelectronics Society-SBMO received 08 June 2016; for review 09 June 2016; accepted 08 Sept 2016 
[13] M. A. Ismail, N. Tamchek, M. R. A. Hassan, K. D. Dambul, J. Selvaraj, N. A Rahim, R. Sandoghchi, F. R. M. Adikan, “A fiber Bragg grating - bimetal temperature sensor for solar panel inverters”, in Sensors, vol. 11, n. 9, p. 8665-8673, 2011, doi:10.3390/s110908665.

[14] A. Othonos, K. Kalli, "Fiber Bragg Gratings Fundamentals and Applications in Telecommunications and Sensing", Artech House, 1999.

[15] R. M. Cazo, T. H. Hattori, L. C. Barbosa, O. Lisbôa, R. C. Rabelo, "Sensor de deformação usando grades de Bragg", in Revista Cientifica Periódica - Telecomunicações, vol. 03, n.2, p. 76-79, 2000, ISSN 1516-2338.

[16] D. Barrera, V. Finazzi, J. Villatoro, S. Sales, V. Pruneri, "Packaged optical sensors based on regenerated fiber Bragg gratings for high temperature applications”, in Sensors Journal, IEEE, vol. 12, no. 1, p. 107-112, 2012. doi: 10.1109/JSEN.2011.2122254.

[17] R. A. Freitas, "Optical fiber temperature sensors for cryogenic application", 2014, 77p. Dissertação (Mestrado Integrado em Engenharia Física), Faculdade de Ciências do Porto, 2014.

[18] E. V. Silva, U. J. Dreyer, K. M. Souza, J. Somenzi, V. J. Babinski, A. B. Di Renzo, F. Mezzadri, J. P. Bazzo, V. Oliveira, H. J. Kalinowski, C. Martelli, J. C. C. Silva, "Medição de temperatura do estator, radiador e mancal de um gerador de potência de 182MW utilizando sensores a fibra óptica”, in VII Congresso de Inovação Tecnológica em Energia Elétrica (VII CITENEL), Rio de Janeiro, 2013.

[19] K. M. Souza, W. Probst, F. Bortolotti, C. Martelli, J. C. C. Silva, "Fiber Bragg grating temperature sensor in a 6.5-MW generator exciter bridge and the development and simulation of its thermal model" in Microwave \& Optoelectronics Conference (IMOC), SBMO/IEEE MTT-S International, p. 1-5, doi: 10.1109/IMOC.2013.6646494, august 2013.

[20] R. M. Measures, "Structural monitoring with fiber optic technology", in Institute for Aerospace Studies, University of Toronto, Academic Press, Canada, 2001, ISBN: 9780080518046.

[21] I. Lourenço Junior, "Monitoramento de propriedades mecânicas de polímeros com sensor á rede de Bragg", 2011, 100p. Tese (Doutorado em Engenharia Elétrica e Informática Industrial), UTFPR, Curitiba, 2011.

[22] M. C. García, J. L. Balenzategui, "Estimation of photovoltaic module yearly temperature and performance based on Nominal Operation Cell Temperature Calculations" inRenewable Energy, vol. 29, issue 12, October 2004, p. 1997-2010, ISSN 0960-1481, http://dx.doi.org/10.1016/j.renene.2004.03.010.

[23] A. M. Reis, N. T. Coleman, M. W. Marshall, P. Lehman, C. E. Chamberlin, "Comparation of PV module performance before and after 11-years offield exposure", in Proceedings of the Conference Record of the 29th IEEE Photovoltaic Specialist Conference, New Orleans, LA, USA, p. 1432-1435. ISSN: 1060-8371, doi: 10.1109/PVSC.2002.1190878.

[24] P. Trinuruk, C. Sorapipatana, D. Chenvidhya, "Estimating operating cell temperature of BIPV modules in Thailand," in Renewable Energy, vol. 34, issue 11, November 2009, p. 2515-2523, ISSN 0960-1481, http://dx.doi.org/10.1016/j.renene.2009.02.027

[25] R. Gottschalg, "Performance characterization of photovoltaic modules", in Photovoltaic Specialists Conference (PVSC), pp. 12651270, 35th IEEE, 2010, doi: 10.1109/PVSC.2010.5614204.

[26] K. O. Hill, B. Malo, F. Bilodeau, D. C. Johnson, J. Albert, "Bragg Gratings fabricated in monomode photosensitive optical fiber by UV exposure through a phase mask", in Applied Physics Letters, vol.62, n. 10, p. 1035-1037, 1993.

[27] E. A. Santolin, I. Lourenço Junior, J. C. C. Silva, V. Oliveira, "Aplicação de Sensores à Fibra Óptica no monitoramento de painéis fotovoltaicos" in MOMAG 2014: $16^{\circ}$ Simpósio Brasileiro de Micro-ondas e Optoeletrônica (SBMO) e $11^{\circ}$ Congresso Brasileiro de Eletromagnetismo (CBMag), Curitiba: UTFPR, p. 837-842, doi: 10.13140/2.1.4445.6969, 2014.

[28] F. Bortolotti, K. M. Souza, J. C. C. Silva, H. J. Kalinowski, "Packaging, characterizationandcalibrationoffiber Bragg gratingtemperaturesensors" in MOMAG 2013: $15^{\circ}$ Simpósio Brasileiro de Micro-ondas e Optoeletrônica (SBMO) e $10^{\circ}$ Congresso Brasileiro de Eletromagnetismo (CBMag), Paraíba, 2013.

[29] GUM,“Avaliação de dados de medição: Guia para a expressão de incertezas de medição”, p. 138, JCGM, 2008.

[30] S. Armstrong, W. G. Hurley, "A thermal model for photovoltaic panels under varying atmospheric conditions" in Applied Thermal Engineering, vol 30, Issues 11-12, p. 1488-1495, 2010, ISSN: 1359-4311, 2010.

Brazilian Microwave and Optoelectronics Society-SBMO received 08 June 2016; for review 09 June 2016; accepted 08 Sept 2016 